\title{
PANFLETOS PARA PIRILAMPOS E MAGNÓLIAS: PROFUNDANÇAS 2 E A ESCREVIVÊNCIA DA MULHER NEGRA COMO MOVIMENTO DE RE- EXISTÊNCIA
}

\author{
Elisiane Santos Santos de Matos \\ Mestra em Letras (Linguagens e Representações) pela Universidade Estadual de Santa Cruz \\ (UESC) \\ elisiane-matos@hotmail.com
}

Sandra Maria Pereira do Sacramento Doutora em Letras (Letras Vernáculas) pela Universidade Federal do Rio de Janeiro (UFRJ) Professora plena da Universidade Estadual de Santa Cruz (UESC) sandramsacramento@hotmail.com

\section{RESUMO}

O presente artigo trata da necessária revisão do cânone literário sob uma perspectiva interseccional, buscando entender como as relações de poder, que subjazem às escolhas das obras literárias referenciais de cada país, concorreram para invisibilidade de obras de autoria feminina e, em maior medida, de autoria de mulheres negras. Tendo como corpus literário o poema Panfletos para pirilampos e magnólias, da poeta negra latino-americana Rita Santana, intenta-se compreender a importância de se realizar rasuras nas representações do presente, respeitando o lugar de fala e promovendo a auto representação das mulheres escritoras, que por muito tempo foram relegadas ao lugar da não representação. Para tanto, utiliza-se como arcabouço teórico: Coutinho (1996); Schmidt (2017); Spivak (2010); Davis (2016); Ribeiro (2017); entre outros.

Palavras-chave: Cânone literário; escritoras negras; feminismo; lugar de fala.

\begin{abstract}
This article deals with the necessary revision of the literary canon from an intersectional perspective, trying to understand how the relations of power, which underlie the choices of the reference literary works of each country, have influenced the invisibility of works of female authorship and to a greater extent, written by black women. Having as a literary corpus the poem Pamphlets for fireflies and magnolias, by Latin American black poet Rita Santana, attempts to understand the importance of performing erasures in the representations of the present, respecting the place of speech and promoting the self representation of women writers, which for a long time were relegated to the place of nonrepresentation. For this, it is used as theoretical framework: Coutinho (1996); Schmidt (2017); Spivak (2010); Davis (2016); Ribeiro (2017); among others.
\end{abstract}

Keywords: Literary canon; black writers; feminism; place of speech. 


\section{Introdução}

A formação dos cânones ocorre num contexto histórico marcado por relações de poder, que buscam fundamento em fatores morais e sociais. Com relação aos cânones literários nacionais, pode-se afirmar que a escolha das obras representativas de determinado país, apesar de se justificar por fatores estéticos, leva mais em consideração os interesses de um sistema literário tradicional - que sobrepõe o homem europeu, heterossexual, participante das classes dominantes aos escritores participantes dos grupos subalternizados, tais como as mulheres, os negros, os colonizados, etc.

A partir da mudança de paradigma possibilitado pelo advento das teorias no bojo da pós-modernidade, a exemplo do Desconstrutivismo, dos Estudos Culturais e PósColoniais, se modifica o foco dos estudos da Literatura Comparada, direcionando-o aos países da América Latina, África e Ásia - antes com pouca ou nenhuma centralidade nestas pesquisas. Segundo Coutinho (1996, p. 69-70), este movimento começa por quebrar o modelo europeu, em benefício de uma literatura mais intercruzada de características advindas desses países, outrora marginais, e de outras culturas:

Nesses locais, onde não há nenhum senso de incompatibilidade entre Literaturas Nacionais e Literatura Comparada, o modelo eurocêntrico até então tido como referência, vem sendo cada vez mais posto em xeque, e os paradigmas tradicionais cedem lugar a construções alternativas ricas e flexíveis, cuja principal preocupação reside na articulação da percepção dos produtos culturais locais em relação com os produtos de outras culturas, máxime daquelas com que a primeira havia mantido vínculos de subordinação. 
Nesse cenário, analisar o poema Panfletos para pirilampos e magnólias, de autoria de poeta negra latino-americana Rita Santana, presente na coletânea Profundanças 2, sob a ótica revisionista do cânone literário, e a partir de uma crítica feminista às hierarquizações, que interseccionam gênero, raça e classe, se faz pertinente devido à urgência de se garantir a auto representação dessas minorias, que subsistem à margem do mercado literário e da sociedade, de uma maneira geral.

\section{Formação dos cânones literários nacionais: relações de poder e invisibilidade das autorias femininas}

Ao descrever as características constitutivas da Literatura Comparada, desde a sua origem científico-causalista, passando por sua fase formalista e acabando na sua revisão possibilitada pela pós-modernidade, Eduardo Coutinho (1996) ressalta o universalismo como uma tentativa, por muito tempo eficaz, de definir a literatura como uma arte nobre. Segue-se que o fazer literário transcende as fronteiras linguísticas, étnicas ou políticas e, portanto, não deve levar estas especificidades socioculturais em consideração:

Marcada no início por uma perspectiva de teor historicista, calcada em princípios científico-causalistas, decorrentes do momento e contexto histórico em que se configurara, e em seguida por uma óptica predominantemente formalista, que conviveu, entretanto, com vozes dissonantes de significativa relevância, a Literatura Comparada atravessou seu primeiro século de existência em meio a intensos debates, mas apoiada em certos pilares, de tintas nitidamente etnocêntricas, que pouco se moveram ao largo de todo esse tempo. Dentre estes pilares, que permaneceram quase inabalados até os anos 70, é impossível deixar de reconhecer a pretensão de universalidade (COUTINHO, 1996, p. 67-68). 
Amparado numa pretensa representação universal, elegeu-se o padrão de literatura europeu e branco como paradigma para todas as outras produções literárias. Estabelecendo este parâmetro formalístico de apreciação, propõe-se uma postura apolítica da crítica literária, como se nos bastidores da formação dos cânones literários nacionais não subsistissem jogos de poder direcionando as escolhas e, consequentemente, relegando aos países que estão fora deste modelo posto, o lugar periférico da não representação.

Ao tomarem como modelo os valores etno e eurocêntricos, os corpora literários afeitos aos Estados-nação têm um papel importante na reduplicação de um imaginário social, que endossa os valores do homem, branco, pagador de impostos. Por isso, o cânone ocidental acabou por relegar as nações colonizadas e não ocidentalizadas ao lugar de objeto narrado, sem possibilidade de auto representação para aqueles que não se encontravam no paradigma dos nomeados como civilizados. Neste contexto de formação dos cânones nacionais, Harold Bloom (1998) apresenta este cenário como uma competição das obras literárias pela sobrevivência no tempo:

O cânone, uma palavra religiosa em sua origem, tem se convertido em uma eleição entre textos que competem para sobreviver, já interpretada essa eleição como realizada por grupos sociais dominantes, instituições educativas, tradições críticas ou, como faço eu, por autores de aparição posterior que se sentem eleitos por figuras anteriores concretas (BLOOM, 1998, p. 195, tradução nossa).

Nesta conjuntura de jogos de poder, Lajolo $(1997$, p. 83) fala sobre a literatura, enquanto linguagem social e poderoso instrumento de gerenciamento das sociedades: 
Linguagem social que se vale das línguas naturais, a literatura em suas diferentes manifestações torna-se instrumento poderoso no gerenciamento das sociedades. Ao formatar o imaginário coletivo, o poder da literatura se exerce de forma mais visível e nisso reside sua maior ameaça: se é verdade que nações são comunidades imaginárias, a literatura é uma das linguagens que esculpem este imaginário, pondo em circulação, discutindo e ressinalizando identidades, valores, crenças e demais elementos de coesão da comunidade que vive esta cultura.

Essa atribuição de gerenciamento social dada à literatura por Lajolo (1997) se coaduna com a análise feita por Rita Terezinha Schmidt (2017) acerca do processo de produção de efeitos de verdade, empreendida pela representação com intuito de instituir o controle ideológico:

Toda representação faz parte de um código simbólico, um sistema de signos que estrutura e materializa a realidade, produzindo um regime de verdade. A representação é o fulcro de toda a prática discursiva. Estamos na representação e somos gerados por ela. E é exatamente por ser a representação tão poderosa em criar realidades e mudar o sentido dessas realidades, articulando uma verdadeira gramática do sistema de uma cultura, que o controle ideológico de seus mecanismos de organização e significação sempre foi a forma mais eficaz de manutenção do poder (SCHMIDT, 2017, p. 87).

A partir dos anos 1970, a Literatura Comparada começa um movimento de transposição de um pensamento mais universalista e centralizado em valores etnocêntricos para uma visão mais descentralizada do mundo - consciente da relação intrínseca com a histórica e considerando as diferenças étnico-culturais de cada cânone nacional. Segundo Coutinho (1996, p. 68-9), essa transposição é impulsionada por duas críticas que aproximam o campo da Literatura Comparada às questões de identidade nacional e cultural: 
O questionamento dessa postura universalizante e a desmitificação da proposta de apolitização, que se tornaram uma tônica na Literatura Comparada a partir dos anos 70, atuaram de modo diferente nos centros hegemônicos e nos focos de estudos comparatistas que poderíamos chamar de periféricos, mas em ambos estes contextos verificou-se um fenômeno similiar: a aproximação cada vez maior do comparatismo a questões de identidade nacional e cultural. No eixo Europa Ocidental/América do Norte, o cerne das preocupações deslocou-se para grupos minoritários, de caráter étnico ou sexual, cujas vozes começaram a erguer-se cada vez com mais vigor, buscando foros de debate para formas alternativas de expressão, e nas outras partes do mundo clamava-se um desvio de olhar, com o qual se pudessem enfocar as questões literárias ali surgidas a partir do próprio locus onde se situava o pesquisador.

No contexto da Literatura Comparada, a tomada de consciência acerca dos problemas gerados pela universalização revela o domínio estabelecido pelo continente europeu, bem como a subalternidade dos países ditos periféricos e colonizados. Esta relação hierárquica se estabelece epistemologicamente, tendo como sujeito a Europa e como objeto todos aqueles países que não são. De modo que, se conforma numa dominação ideológica fundada na ideia cientificista da modernidade de que há diferentes raças humanas, e mais, que há raças humanas superiores a outras. No contexto teórico brasileiro, Carneiro (2011, p. 15-6) define esse racismo científico como uma das heranças da escravidão, ao passo que estabelece como um desdobramento deste quadro a existência das desigualdades sociais no Brasil:

Uma das heranças da escravidão foi o racismo científico do século XIX, que dotou de suposta cientificidade a divisão da humanidade em raças e estabeleceu hierarquia entre elas, conferindo-lhes estatuto de superioridade ou inferioridade naturais. Dessas ideias decorreram e se reproduzem as conhecidas desigualdades sociais que vêm sendo amplamente divulgadas nos últimos anos no Brasil. 
Ainda segundo Carneiro (2011, p. 69), embora o conceito de raça seja insustentável biologicamente, ele se mantém inscrito no campo da linguagem pelo seu significado político:

A ciência vem revelando a falácia do conceito de raça do ponto de vista biológico. Essa constatação científica é utilizada para minar as reivindicações de políticas específicas para grupos discriminados com base na raça ou na cor da pele. As novas pesquisas destroem as bases do racialismo do século XIX, que consagrou a superioridade racial dos brancos em relação a outros grupos humanos, justificando agressões e privilégios, mas elas ainda não tiveram impacto sobre as diversas manifestações de racismo em ascensão no mundo inteiro, e sobre a persistente reprodução de desigualdades que ele gera, o que reafirma o caráter político do conceito de raça, a sua permanência e atualidade, a respeito de ser insustentável do ponto de vista biológico.

Seguindo o modelo binário que hierarquiza as diferenças, o negro, a mulher, o índio, enfim todos aqueles que não são homem, ocidental, branco são relegados ao status de seres inferiores. Inaptos à intelectualidade, seriam incapazes de escrever obras compatíveis com as exigências formalísticas prescritas pela crítica literária, na formação dos cânones nacionais. Assim, segundo Coutinho (1996, p. 69), a mudança de paradigma nos estudos comparados significa uma nova oportunidade à disciplina:

O desvio de olhar operado no seio do comparatismo, como resultado da consciência do teor etnocêntrico que o dominara em fases anteriores, emprestou novo alento à disciplina, que atingiu enorme efervescência justamente naqueles locais até então situados à margem e agora tornados postos fundamentais no debate internacional.

Junto com esta mudança de padrão, inicia-se um processo de dissociação entre a obra literária e o mundo ideal - o que, nas palavras de Schmidt (2017, p. 40), significa 
dizer que "a obra literária não habita um mundo ideal, mas o mundo real do qual se alimenta e no qual atua, refletindo e interpretando o mesmo e, assim, influenciando ideias valores e ação".

Nesse contexto de ruptura do paradigma da modernidade e de aproximação entre o campo da Literatura Comparada às questões concernentes à identidade, o pósestruturalismo funciona como um facilitador para que a teoria feminista problematize a questão da diferença. Isto porque, este movimento de oposição aos princípios teóricos do estruturalismo fundamentados no logos impõe uma severa crítica às noções de identidades essenciais do gênero, que se ancoram na estrutura binária de compreensão do mundo.

Se o modelo universal é passível de crítica e rasura, então, é viável a construção de uma teoria que ponha em xeque a ideia da diferença sexual como algo natural e biologicamente explicável. Logo, será a partir da ideia de uma diferença culturalmente construída, a fim de promover uma hierarquização entre os sexos, que a segunda onda do movimento feminista vai desenvolver suas pautas. É importante pontuar que é no seio da segunda onda, por volta das décadas de 1960 e 1970, que o movimento feminista negro vai dar seus primeiros passos em direção a uma organização política de enfrentamento e ruptura, inicialmente nos Estados Unidos, e depois em outros países, incluindo o Brasil. Fernandes (2016, p. 697) descreve as barreiras enfrentadas pelas mulheres negras dentro do próprio movimento feminista:

Autoras negras como Michele Wallace (2008), Patricia Collins (2001) ou Lélia Gonzalez (1984), entre outras, abordaram a dificuldade de atuação política significativa nos movimentos feminista e negro que já estavam organizados nos Estados Unidos nas décadas de 1960 e 1970 e, no Brasil, em 1980. De um lado, as mulheres negras foram pressionadas a aceitar 
uma posição secundária no movimento negro, já que a luta por igualdade racial não tinha como bandeira o rompimento dos direitos estabelecidos no sistema patriarcal. [...]. De outro lado, as mulheres negras tiveram suas experiências ignoradas no movimento de mulheres em nome de uma homogeneização de vivência feminina, refletida no sloganall women are oppressed. O lema do movimento feminista homogeneizava as opressões e, assim, ignorava variáveis como raça, classe, orientação sexual, religião ou etnia e os modos específicos como elas interveriam.

É também na possibilidade de crítica ao conteúdo das obras literárias, para além da mera análise formalista, que as teorias feministas encontram lugar para um exame mais detalhado com relação à imposição de identidades fixas e essencialistas. Estas configurações das identidades relegam as mulheres os postos menos valorizados da sociedade, como esclarece Schmidt (2017, p. 84-5) ao estabelecer a conexão entre o pensamento pós-estruturalista e a necessidade de se rever o essencialismo imposto nas relações de gênero:

No impasse entre mulher e gênero, categorias vistas como posições essencialistas/não-essencialistas, o pós-estruturalismo teve grande influência. A importância dada à linguagem e às representações nas reflexões teóricas sobre os aspectos etno e logocêntricos da episteme ocidental moderna privilegiou a dimensão da cultura sobre as determinações econômicas e sociais. Foi nesse terreno que o pósestruturalismo realizou sua crítica à lógica da identidade e decretou a eclipse do sujeito. O conceito de gênero, ao postular a construção cultural da diferença, destacando a dimensão relacional no movimento constitutivo da própria diferença, portanto, opondo-se às identidades fixas, encontrou no pós-estruturalismo um ambiente favorável.

Entendida como parte constituinte do mundo real, num movimento recíproco de influências - a escrita literária pode funcionar como uma ferramenta de exclusão daqueles que não interessam, nas palavras de Judith Butler (2017), ou os subalternizados, 
utilizando a terminologia encontrada nas obras de Spivak (2010). Negar a fala, e, portanto, a auto representação é situar estes grupos à margem de qualquer possibilidade de poder, já que, segundo Rich (1983), em um mundo onde a linguagem e o nomear são formas de exercer o poder, o silêncio significa opressão e violência. Mas quais seriam estes seres, cujas falas vêm sendo silenciadas e para quem este silenciamento interessa? É, nesta questão, que este artigo irá se ater no próximo item.

\section{Profundanças 2: lugar de fala, representação e feminismo negro}

Segundo Spivak, no livro Pode o subalterno falar?, cuja primeira publicação data de 1985, sendo republicado em 1998 e traduzido para o português em 2010, o termo subalterno corresponde às "camadas mais baixas da sociedade constituídas pelos modos específicos de exclusão dos mercados, da representação política e legal, e da possibilidade de se tornarem membros plenos no estrato social dominante" (SPIVAK, 2010, p.12). Na obra O que é lugar de fala?, publicada em 2017, Djamila Ribeiro teoriza acerca da expressão lugar de fala, associando sua acepção ao conceito de feminist standpoint cunhado por Patricia Hill Collins. O conceito criado pela teórica norteamericana correspondente à necessidade de se levar em consideração o ponto de partida ou o locus social, ao qual pertencem as diversas mulheres, que compõem o sujeito do feminismo. Em tempo, ao tratar do lugar de fala, Ribeiro (2017) utiliza como outra fonte teórica Grada Kilomba, em Plantation Memories: Episodes of Everyday Racism. Claro que esta discussão se dá num contexto de problematização do sujeito universal mulher enquanto categoria que não consegue dar conta de representar mulheres negras, indígenas, transexuais, lésbicas, etc. Conforme Ribeiro (2017, p. 59-60): 
A nossa hipótese é que a partir da teoria do ponto de vista feminista, é possível falar de lugar de fala. Ao reivindicar os diferentes pontos de análise e a afirmação de que um dos objetivos do feminismo negro é marcar o lugar de fala de quem as propõem, percebemos que essa marcação se torna necessária para entendermos realidades que foram consideradas implícitas dentro da normatização.

Também se podem realizar conexões entre o conceito de lugar de fala e a ideia de locus enunciativo presente na construção teórica da chamada política de lugar, ao qual Schmidt (2017, p. 175) faz referência ao qualificá-lo como um lugar psíquico/social/cultural/histórico ocupado pelos sujeitos do feminismo:

[...] o feminismo, em geral, e a crítica feminista, em particular, retomam a questão de valor por entender que este é também um termo pertinente ao discurso político de emancipação - emancipação da exploração, da marginalização, do preconceito e da invisibilidade. Valor, nesse contexto, é um dos elementos constitutivos da chamada "política de lugar", expressão formulada por Adrienne Rich no ensaio "Notes toward a politics of location" (1984), e que diz respeito a um locus de enunciação psíquico/social/cultural/histórico, onde se constituem e se inscrevem os sujeitos no feminismo para investigar as relações entre o estético e o político entre a experiência e o discurso, entre a teoria e a prática.

Quando Sojourner Truth, mulher negra e ex-escrava, proferiu seu discurso Não sou eu uma mulher?, em uma convenção de mulheres em Akron, Ohio, em 1851, as palavras dela deixam clara a consciência do seu lugar de enunciação, do seu locus social, denotando que, neste momento da história feminista, já havia mulheres com um pensamento interseccionalizado, como se nota na perspectiva teórica de Davis (2016, p. 73): 
Quando essa mulher negra se levantou para falar, sua resposta, os defensores da supremacia masculina também traziam uma profunda lição para as mulheres brancas. Ao repetir sua pergunta, "Não sou eu uma mulher?". Nada menos do que quatro vezes, ela dispunha o viés de classe e o racismo do novo movimento de mulheres. Nem todas as mulheres eram brancas ou desfrutavam do conforto material da classe média e da burguesia. Sojourner Truth era negra - uma ex-escrava -, mas não era menos mulher do que qualquer uma de suas irmãs brancas na convenção. $O$ fato de sua raça e de sua situação econômica serem diferentes daquelas das demais não anulava sua condição de mulher. E, como mulher negra, sua reivindicação por direitos iguais não era menos legítima do que a das mulheres brancas de classe média.

Nesse sentido, Ribeiro (2017, p. 21) corrobora com a fala de Davis:

Entretanto, o que percebemos com o discurso de Truth e com as histórias de resistências e produções de mulheres negras desde antes o período escravocrata e, consequentemente, com a produção e atuação de feministas negras é que esse debate já vinha sendo feito; o problema, então, seria a sua falta de visibilidade.

Então, pode-se acrescentar que o olhar feminista pelo viés da interseccionalidade já vinha também sendo idealizado por feministas, como Angela Davis. Ou seja, apesar de ser creditado à terceira onda do feminismo, o olhar interseccional, em alguma medida, já vinha sendo pensado desde a primeira onda, sendo vislumbrado pelo feminismo negro, a partir dos anos 1960 e 1970. Ainda, nesta argumentação, Ribeiro (2017, p. 21-2) acrescenta:

Essa discussão já vem sendo feita desde a primeira onda, como nos mostra Truth, assim como na segunda onda, como podemos ver nas obras de feministas negras como bell hook, Audre Lorde entre outras, apesar de ambas não serem caracterizadas por esse tipo de reivindicação pela perspectiva dominante. 
Tem-se como estabelecido que a gênese do movimento feminista é branca e ocidental. E, apesar de num segundo momento as pautas feministas passarem a visualizar as mulheres de outras etnias, foi preciso que na segunda onda, mulheres negras realizassem uma fissura dentro do próprio movimento, a fim de garantir que suas demandas fossem priorizadas em alguma medida. Collin $(2009$, p. 62) fala acerca dessa priorização das pautas ocidentais, como uma atitude fundada em certo etnocentrismo por parte das feministas da primeira onda:

Deve-se notar que as teorias feministas foram elaboradas no contexto do pensamento e da situação ocidentais embora, no segundo momento, amplie sua curiosidade para outras culturas. Essa persistência do "ocidentocentrismo" na contestação do falocentrismo foi muitas vezes criticada.

Ao falar sobre a crítica empreendida por Lélia Gonzalez, em Racismo e Sexismo na Cultura Brasileira, acerca da hierarquização de saberes, como produto de classificação racial da população, Ribeiro $(2017$, p. 24-5) chega aos indícios sobre quais vozes foram silenciadas e a quem interessava este silenciamento:

Ou seja, reconhecendo a equação: quem possui o privilégio social possui o privilégio epistêmico, uma vez que o modelo valorizado e universal de ciência é branco. A consequência dessa hierarquização legitimou como superior a explicação epistemológica eurocêntrica conferindo ao pensamento moderno ocidental a exclusividade do que seria conhecimento válido, estruturando-o como dominante, assim, inviabilizando outras experiências do conhecimento. Segundo a autora, o racismo se constituiu "como a 'ciência' da superioridade eurocristã (branca e patriarcal)". Essa reflexão de Lélia Gonzalez nos dá uma pista sobre quem pode falar ou não, quais vozes são legitimadas e quais não. 
Então, os grupos não pertencentes às categorias prescritas pelo paradigma epistemológico europeu-branco-patriarcal, que dita um mundo a partir dos esquemas binários de representação, estarão na periferia do sistema de poder - restando-lhes serem descritos pelo olhar vertical daqueles que detêm o domínio da palavra e do saber. Neste contexto, mulheres, negros, índios, gays, lésbicas, transexuais são relegados à categoria de objetos e, por que não dizer, abjetos.

E, se "a comunidade se situa a si mesma em relação com uma tradição, se adapta ao presente e se projeta em direção ao futuro" (MIGNOLO, 1998, p. 237, tradução nossa), então, tem-se que estas minorias, não representadas no passado, se não promoverem uma rasura nas representações do presente, consequentemente, não estarão contempladas nas projeções para o futuro.

Acontece que, na contramão de um poder que se institui sempre há uma resistência que se instala, embora nem sempre esta ação contrária ao poder seja narrada pela historiografia do vencedor, ou nas palavras de Riot-Sarcey $(2009$, p. 184) para o Dicionário Crítico do Feminismo:

Definido como um "modo de ação", o poder se torna elemento constitutivo das sociedades, que não se pode conceber sem a resistência que ele engendra. No entanto, a interação entre poder e resistência não é sempre perceptível, pois a ordem dominante se reconstitui apagando os traços de sua contestação.

Se a fala é a principal agência, que garantiria a autonomia dos sujeitos subalternos, possibilitá-la, então, constitui-se em um ato de resistência diante da imposição de um modelo branco, europeu, patriarcal, heteronormativo. No prefácio ao livro Profundanças 2, Galdino (2017) faz referência ao termo re-existências - um jogo 
entre as palavras resistir e existir. Que pode ser explicada da seguinte maneira: continuar existindo, ou seja, sobreviver aos atos de violência (sejam eles epistemológicos, psíquicos, físicos), geralmente sofridos pelas minorias, equivale ao ato de resistir.

Portanto, o termo re-existência englobaria estas duas ações de rebeldia contra um sistema opressor, ao tempo em que destaca a natureza política da obra:

Odiadores não representam a totalidade do mundo. É preciso arrancar esperança aos dias e lançá-la em garrafas, balões, ruas, muros, livros. Cá estamos para dizer que a literatura é também o nosso foco de reexistência aos golpes - sejam eles nas grandes esferas ou nos circuitos íntimos (GALDINO, 2017, p. 7).

Nota-se que, a obra Profundanças 2, desde sua primeira edição lançada em 2014, persiste em possibilitar que as vozes de mulheres subalternizadas falem por si e a partir do seu olhar acerca das temáticas afeitas ao seu cotidiano, bem como a outros universos que permeiam o seu fazer poético, mas "mais do que compartilhar experiências baseadas na escravidão, racismo e colonialismo, essas mulheres partilham processos de resistências" (RIBEIRO, 2017, p. 26).

De igual modo, ao compor sua lista de poetas e prosadoras por mulheres negras, brancas, lésbicas, heterossexuais, transexuais não binárias, a obra mostra seu caráter interseccional. $E$, na medida em que também é composta por homens, entre seus profissionais, em fotografia, a obra foge ao dualismo imposto pela linguagem, optando pelo neologismo fotógrafes para não utilizar o universal, sempre masculino. Remetendo ao modelo branco/heterossexual/civilizado, o universal masculino foi eleito como única via de representação do todo, como descreve Collin (2009, p. 63): "Com efeito, a dominação masculina se apropriou do universal, truncando-o. A libertação das mulheres 
não é somente a superação de uma injustiça, mas também a manifestação de uma dimensão de relação com o mundo, omitida até hoje".

Conforme o exposto chega-se à constatação de que Profundanças 2 caracteriza-se como uma obra pós-moderna, insurgindo-se contra as formas implícitas e naturalizadas de subordinação, com intuito de "dar visibilidade à autoria feminina e, assim, reconstruir a voz da mulher e suas representações no contexto da natureza agendada da autoridade/paternidade cultural que funda o prestígio da função autoral" (SCHMIDT, 2017, p. 87).

Segundo Lillian S. Robinson (1998), no que concerne à adesão ao cânone literário nacional, às barreiras impostas às mulheres escritoras, por muito tempo justificadas por questões meramente estéticas, deveriam ser postas em discussão, a fim de sofrerem modificações ou até mesmo serem substituídas:

Mas as questões estéticas não se podem esquivar durante muito tempo. Devemos compreender sim o que se reivindica é que muitos dos textos escritos por mulheres que foram redescobertos ou reavaliados coincidem com os critérios existentes ou sim, em troca, esses mesmos critérios excluem intrinsecamente ou tendem a excluir as mulheres e, portanto, se deveriam modificar ou substituir (ROBINSON, 1998, p. 124, tradução nossa).

Ainda no que se relaciona à negativa de acesso ao cânone, Schmidt $(2017$, p. 58) afirma que, ao negar acesso às mulheres a determinados temas, com a justificativa de que elas naturalmente não nasceram com habilidades intelectuais para compreendê-los, constrói-se em torno do sexo feminino a ideia de um status intelectivo inferior:

Com isso, não só se subtrai significância à experiência feminina, mas também se relega a mulher escritora a um status inferior, exatamente 
por ela não explorar temas supostamente de maior abrangência, ou seja, aqueles considerados como os grandes temas da literatura, os conflitos do homem consigo mesmo, com Deus, com a natureza e, frequentemente, com a mulher, a "outra". Também no contexto dessa crítica se observa que o que se pode tomar como meros acidentes léxicos, isto é, o fato do antecedente humano tomar invariavelmente o pronome "ele" e o fato da generalização humana ser sexualmente particularizada com o substantivo "homem", assume uma dimensão política na medida em que reproduz a codificação de uma relação de poder que assegura a invisibilidade do feminino.

Nesse âmbito, a coletânea Profundanças 2 é um instrumento crítico e de resistência à construção de um cânone literário composto de obras autorizadas por uma crítica, que marginaliza o feminino e propõe o masculino como paradigma para a existência humana. Ao aliar a força do trabalho colaborativo - haja vista que todas as fases de produção da obra se fizeram sem remuneração dos profissionais envolvidos - à potência do universo $w w w$, a coletânea conseguiu publicar, nesta mídia de grande alcance, que é a internet, vozes que, em sua maioria, provavelmente, ficariam à margem do mercado literário.

As mulheres publicadas pela coletânea fazem um movimento em direção à possibilidade de se auto narrarem. Inseri-las no mercado literário oportuniza que outras mulheres se sintam representadas em suas falas e encorajadas a empreenderem uma autorrepresentação. Riot-Sarcey (2009, p. 187) descreve a autonarrativa como um percurso que vai da submissão à liberdade:

A passagem do sujeito submisso a sujeito livre supõe o questionamento das formas do poder que se exerce sobre cada indivíduo. 0 poder de dizer eu é também uma luta contra as formas de sujeição - contra a submissão da subjetividade - de que as mulheres são especialmente vítimas. Alcançar o estatuto de sujeito livre faz parte da aprendizagem do poder, no respeito por si e pelo outro. 
Voltando às questões das escolhas realizadas para a formação dos cânones nacionais, tem-se como claro que elas privilegiam obras de autoria masculina e branca. De forma majoritária, estes escritos literários representam o sujeito feminino preso à imanência e desqualificado para qualquer atividade intelectual. Segundo Schmidt (2017), a imagem das mulheres trazida pelos textos canônicos aprisionava-as ao campo da imanência, negando-lhes qualquer acesso ao transcendente. À mulher era impossível qualquer autonomia de ser, ou seja, sempre narrada pela fala do sujeito universal, masculino, branco, restava-lhe a mera repetição dos modelos prontos.

Simbolizando a total antítese dos escritores privilegiados pelo cânone literário, as obras de autoria feminina negra foram relegadas ao lugar das literaturas marginais. 0 status animalesco, que mescla força e sensualidade, sempre afastou o corpo hipersexualizado da mulher negra das possibilidades de acesso à esfera intelectual. Desse modo, mulheres de ancestralidade africana estiveram à margem da literatura, enquanto escritoras e, quando presentes nos enredos literários, eram sempre descritas com características vinculadas à natureza, sensualizadas e ligadas às atividades maternais, domésticas e não intelectivas. Como se nota nas palavras de Fernandes (2016, p. 696): “Hiperssexual, masculina, promíscua, dominadora e forte: a mulher negra foi construída ao longo de séculos de opressão racista e machista, potencializando o que havia de pior nas configurações estigmatizadas dos negros e das mulheres".

Na obra Mulheres, raça e classe, Davis (2016, p. 23-4) explica que muitas das características pertencentes às mulheres negras - não compartilhadas pelas mulheres brancas- que entraram em choque com a ideia de feminilidade do século XIX, advêm, em 
grande medida, da forma violenta com que foram tratadas durante o processo de escravização:

Obrigadas pelos senhores de escravos a trabalhar de modo tão "masculino" quanto seus companheiros, as mulheres negras devem ter sido profundamente afetadas pelas vivências durante a escravidão. Algumas, sem dúvida, ficaram abaladas e destruídas, embora a maioria tenha sobrevivido e, nesse processo, adquirido características consideradas tabu pela ideologia da feminilidade do século XIX.

Em outro momento da obra, Davis (2016, p. 41) reitera a ideia de resistência das mulheres negras, acrescentando que esta característica era legada as descendentes dessas escravas, que, embora livres, teriam que lidar com todas as consequências históricas do processo de escravização pelo qual passou o seu povo:

[...] as experiências acumuladas por todas essas mulheres que labutaram sob o chicote de seus senhores, trabalharam para sua família, protegendo-a, lutaram contra a escravidão e foram espancadas, estupradas, mas nunca subjugadas. Foram essas mulheres que transmitiram para as suas descendentes do sexo feminino, nominalmente livres, um legado de trabalho duro, perseverança e autossuficiência, um legado de tenacidade, resistência e insistência na igualdade sexual - em resumo, legado que explicita os parâmetros para uma nova condição da mulher.

Por conseguinte, dentre as falas silenciadas pelos cânones literários, tem-se a voz das mulheres africanas, afro-brasileiras, latinas - lugares de pertencimento da escritora brasileira, nascida na Bahia, Rita Santana. O poema de sua autoria Panfleto para Pirilampos e Magnólias, publicado na presente coletânea Profundanças 2, que será analisado a seguir, reflete bem esta dinâmica entre existir e resistir, tendo a literatura como instrumento reflexivo da realidade social e política. 


\section{Panfletos para pirilampos e magnólias: Rita Santana, escritora negra e latino-americana}

Nascida em Ilhéus, Rita Santana é escritora, atriz e professora. Graduada em Letras pela Universidade Estadual de Santa Cruz, onde assumiu umas das coordenações do projeto Universidade em Verso; além de ser especialista em Cultura e História Afrobrasileira. Tendo estreado na literatura em 2004 com o prêmio Braskem na categoria literatura, com o livro Tramela. Sua trajetória literária é seguida por outras publicações: o livro de poesia Tratado das Veias, publicado pelo Selo Letras da Bahia, em 2006; Alforrias - livro de poesia publicada pela EDITUS (Editora da UESC), em 2012, com segunda impressão em 2016; e a publicação do poema Adusto na revista Organismo, em 2015.

Nota-se pela biografia de Rita Santana que ela participa do grupo de exceções à regra de autoras inéditas, ou seja, nunca antes publicadas, presentes na obra Profundanças 2. Sua poesia foi escolhida como objeto de análise deste artigo, em primeiro lugar, pela consciência do locus enunciativo transmitido pelas palavras da poeta que se posiciona enquanto mulher latina e afro-brasileira. Em segundo lugar, pela riqueza de referências, denotando a intertextualidade presente na criação do texto literário, que se coaduna com o movimento de desconstrução dos essencialismos empreendido pelas teorias da pós-modernidade. Por fim, em terceiro lugar, pela importância da temática tratada no poema, a saber: o contexto político brasileiro pós-impeachment da expresidenta Dilma.

As alusões de que faz uso Santana (2017) corroboram para a construção do sentido do poema Panfleto para Pirilampos e Magnólias, haja vista que a obra equivale a um mosaico de citações, construído a partir da absorção e transformação de outros 
textos apreendidos pela escritora, escritos literários ou dispostos em outras mídias, como músicas, filmes, paisagens, etc.

Feitas estas considerações, passa-se à análise do poema Panfleto para Pirilampos e Magnólias, que tem seu início marcado por certa tensão: Há um aneurisma no cérebro do País / Esperando o tempo da explosão. / Pirilampos apagados / Buscam faróis na noite da Baía, / No mistério do dique, das docas (SANTANA, 2017, p. 153). Sendo a autora do poema, brasileira, nascida na Bahia, e associando a expressão do dique, das docas ao contexto baiano, se deduz que Santana (2009) refere-se ao Brasil, quando afirma que existe um aneurisma no cérebro do país, o que conota que a nação passa por um momento delicado. Soma-se a isto a descrição dos pirilampos que, apesar de terem como principal característica a emissão de luz, são descritos, como "apagados" - o que faz crer que algo não está em ordem no contexto brasileiro.

Em primeira pessoa, Santana (2009, p. 153), afirma: "Celebro manifestos insurrectos / Onde a Poesia cataclisma, / Hekatomba. / Estampo relâmpagos nos muros / Uma hemorragia inunda / De sangue o oxigênio das horas. / O sangue pletora utopias, risos e chamas". Os manifestos, que a autora celebra, são insurgentes, ou seja, são manifestações contrárias a algo, manifestações disruptivas, que levam diretamente a um lugar, onde a poesia cataclisma, ou seja, pretende uma modificação significativa na maneira como se organiza uma determinada sociedade. Mesmo pelo ponto de vista ambiental, o cataclisma também tende a uma alguma forma de mudança, de transição, posto que este termo esteja relacionado às grandes catástrofes ambientais e o que se segue, é uma imagem ainda mais forte. Nos próximos versos, percebe-se que o aneurisma existente no cérebro do país, ou já explodiu, ou está em vias de, pois "Uma 
hemorragia inunda / De sangue o oxigênio das horas. / O sangue pletora utopias, risos e chamas" (SANTANA, 2017, p. 153).

Nos próximos versos, a poeta faz referência à personagem Blimunda, do romance Memorial do convento, escrito por José Saramago e publicado em 1982. Apesar de a personagem ter tons sensuais e uma existência fora das regras morais condicionadas às mulheres daquele momento histórico, a saber, início do século XVIII, Santana (2017) associa a figura de Blimunda ao ato de recolher vontades: “Apesar da grande noite que se abate sobre o País, / O combate permanece no silêncio das tumbas, / Na obscuridade dos pesadelos, / Nas vontades recolhidas por Blimunda. / O horror retumba sobre as casas / Enquanto engenho palavras / E lavro novos âmagos" (SANTANA, 2017, p. 153). Talvez, este movimento de recolher vontades por uma personagem, que vive sua sexualidade de maneira tão livre, simbolize algum retrocesso dos direitos das mulheres, no contexto nacional, mas esta é apenas uma suposição.

Neste ponto do poema, Santana (2017, p. 153) retira o leitor da ambiência brasileira e leva-o a viajar: "Na Colômbia, / Há Ceibas na estrada para Córdoba, / E suas raízes guardam segredos / De viajantes, de plantadoras de café, / De homens que bebem a noite / E sorvem nossas magnólias / (Magnólias brancas de Billie)". Ao descrever que existem ceibas, na estrada para Córdoba, um gênero de plantas geralmente encontrado em países da América Central e do Sul e também no Sudeste da Ásia, a autora constrói um imaginário visual voltado para o que a Europa definiu como periferia do mundo.

Esse imaginário de Santana (2017) corrobora com o movimento de desconstrução, propiciado pelas teorias da pós-modernidade, pelo qual passam os estudos comparatistas, que tira do foco a Europa, que, por muito tempo, serviu de modelo 
estilístico para a literatura, o que, na análise de Coutinho (1996, p. 68), levou à supervalorização e universalização do modelo europeu:

\begin{abstract}
Em nome de uma pseudodemocracia das letras, que pretendia construir uma História Geral da Literatura ou uma poética universal, desenvolvendo um instrumental comum para a abordagem do fenômeno literário, independente de circunstâncias específicas, os comparatistas, provenientes na maioria do contexto euro-norteamericano, o que fizeram. Conscientemente ou não, foi estender a outras literaturas os parâmetros instituídos a partir de reflexões desenvolvidas sobre o cânone literário europeu (e por europeu entendase o cânone constituído basicamente por obras literárias das potências econômicas do oeste do continente). O resultado inevitável foi a supervalorização de um sistema determinado e a identificação deste sistema - o europeu - com o universal.
\end{abstract}

Outra referência, que merece destaque neste recorte do poema, é a menção que a poeta faz a Billie Holiday, cantora e compositora estadunidense de jazz, também conhecida como Lady Day, que interpretou uma das maiores canções de protesto contra o racismo e o linchamento de negros nos Estados Unidos: StrangeFruit, cuja letra advém de um poema escrito, em 1936, por Abel Meerepol, judeu, professor universitário, escritor e compositor.

A letra da música faz referência aos numerosos casos de linchamentos de homens negros ocorridos nos Estados Unidos, ao horror e à violência sofrida pelos afroamericanos durante os anos de segregação racial. Davis (2016) faz uso do capítulo "Estupro, racismo e o mito do estuprador negro", na obra Mulheres, Raça e Classe, para analisar como estes casos de linchamentos estão imbricados numa política eugenista posto que a acusação de estupro funcionou durante um longo período como uma poderosa arma para legitimar a morte de pessoas negras, vítimas de linchamento. 
Os linchamentos eram realizados, tendo como pano de fundo o mito do estuprador negro e, segundo Davis (2016, p. 186), implicam ainda na relação entre o homem negro propício a cometer atos de violência e a mulher negra, incitadora sexual. Ou seja, duas construções ideológicas realizadas a fim de manterem o homem branco ocidental isento de qualquer culpa:

\begin{abstract}
A imagem fictícia do homem negro como estuprador sempre fortaleceu sua companheira inseparável: a imagem da mulher negra como cronicamente promíscua. Uma vez aceita a noção de que os homens negros trazem em si compulsões sexuais irresistíveis e animalescas, toda a raça é investida de bestialidade. Se os homens negros voltam os olhos para as mulheres brancas como objetos sexuais, então as mulheres devem por certo aceitar as atenções sexuais dos homens brancos. Se elas são vistas como "mulheres fáceis" e prostitutas, suas queixas de estupro necessariamente carecem de legitimidade.
\end{abstract}

Segundo a intelectual negra, "nos Estados Unidos e em outros países capitalistas, as leis contra estupros foram, em regra, elaboradas originalmente para proteger homens das classes mais altas, cujas filhas e esposas corriam o risco de ser agredidas" (DAVIS, 2016, 177). Tal constatação reverbera até a atualidade em países como o Brasil, onde o número de notificações de violências, entre elas o estupro e o feminicídio, é maior em relação às mulheres negras e pobres - dados que podem ser comprovados pelo Mapa da Violência de 2015.

Ainda segundo Davis (2016, p. 180), "uma das características históricas marcantes do racismo sempre foi a concepção de que os homens brancos - especialmente aqueles com poder econômico - possuiriam um direito incontestável de acesso ao corpo das mulheres negra", o que naturaliza as violências sexuais empreendidas por homens 
brancos contra mulheres negras durante o período de escravização, bem como nos anos subsequentes à abolição da escravatura, com manutenção até a contemporaneidade.

Seguindo sua argumentação sobre as implicações racistas que levam ao mito do estuprador negro, baseado no argumento de que as características animalescas dos homens de minorias étnicas lhes deixam mais propícios a cometer violência sexual contra mulheres, Davis (2016, p. 177), relata a discrepância entre notificações de estupros realizados por homens brancos e por homens negros:

$\mathrm{O}$ que acontece com as mulheres da classe trabalhadora, em geral, tem sido uma preocupação menor por parte dos tribunais; como resultado, são consideravelmente poucos os homens brancos processados pela violência sexual que cometeram contra essas mulheres. Embora estupradores raramente sejam levados à justiça, a acusação de estupro tem sido indiscriminadamente dirigida aos homens negros, tanto culpados quanto inocentes. Por isso, dos 455 homens condenados por estupro que foram executados entre 1930 e 1967, 405 eram negros.

Ocorre que a constatação de que a maioria dos linchamentos empreendidos contra homens negros, acusados de estupro, era originada de acusações injustas, o que levou à desaprovação das mulheres negras e, consequentemente, pouca aderência deste segmento de mulheres ao movimento antiestupro nos Estados Unidos:

O nó histórico que ata as mulheres negras (sistematicamente abusadas e violadas por homens brancos) aos homens negros (mutilados e assassinados devido à manipulação racista das acusações de estupro) apenas começou a ser reconhecido de modo significativo. Sempre que as mulheres negras desafiaram o estupro, elas expuseram simultaneamente o uso de acusações falsas de estupro enquanto arma mortal do racismo contra seus companheiros (DAVIS, 2016, p. 178). 
Dando continuidade à leitura do poema, Santana (2017, p. 153) vai construindo um imaginário todo voltado às questões identitárias do Sul do globo, mas, desta vez, foca de maneira mais incisiva nas mulheres, estabelecendo algumas relações: "Mulheres que mascam tristezas, fumos. / Ceibas mulheres que sustentam o céu, / E acolhem ancestralidades ameríndias. / Assim, desmoronam colinas inteiras dentro de mim".

Primeiro, a autora associa o ato de mascar fumo ao de mascar tristezas, depois liga estas mulheres a uma ancestralidade, ou seja, às memórias de antepassados, que, no poema, corresponde aos antepassados ameríndios - índios das Américas. Dito de outra maneira, o povo nativo, do lugar, depois chamado Brasil, e os descendentes destes povos, que habitavam o continente americano, antes da chegada dos portugueses. Nota-se que esta imagem de mulheres, que mascam tristezas, assim como mascam fumos, bem como a ligação com a ancestralidade indígena, mexe com a autora, quando ela relata que “assim, desmoronam colinas inteiras dentro de mim" (SANTANA, 2017, p. 153).

Embora tenham a tristeza como característica presente, as mulheres descritas por Santana (2017) são fortes, o que resta claro na análise do verso "Ceibas mulheres que sustentam o céu", no qual a autora cria uma imagem mental, que associa as mulheres às ceibas, espécie de planta que remete à parte Sul do globo, ao passo que salienta sua capacidade e demonstração de força ao sustentar o céu.

Por muito tempo, e conceituação da mulher negra como possuidora de um corpo forte por natureza foi utilizada com o intuito de escravizá-la, nas mais diversas instâncias, mas, no texto de Santana (2017), esta característica é empregada de maneira positiva. Esta concepção de corpo ligada a uma construção cultural e histórica, muito presente na criação intelectual da poeta em análise, entra em consonância com o pensamento de Grosz (2000, p. 76), que define corpo como instância cultural e uma produção da 
natureza: “O corpo é visto como um objeto político, social e cultural por excelência e não o produto de uma natureza crua, passiva, que é civilizada, superada, polida pela cultura. O corpo é um tecido cultural e produção da natureza".

O poema continua descrevendo um contexto pouco otimista para a poeta que se verifica em palavras como: desolação, silêncios, lassidão, que estão dispostas nos versos que seguem: "Há acordes de desolação, / Sinfonia de silêncios, / Lassidão dos sonhos, das crenças. / Atavismos seculares nas paredes, / Nos retratos, nas páginas diárias da História. / Nosso leito está vazio. / Nosso eito, sem arado. / Somos um rio seco, sem curso" (SANTANA, 2017, p. 153).

Neste ponto, destaca-se a escolha de Santana (2017) pela palavra atavismo, que, em biologia, diz respeito à chamada reminiscência evolutiva, ou seja, o reaparecimento de uma característica biológica que esteve ausente por algumas gerações. Ocorre que este atavismo aludido na obra não está apenas nas paredes, mas também nos retratos, e, sobretudo, "nas páginas diárias da História". Pode-se inferir, em nível de hipotético, neste fragmento, que algum acontecimento, instituição ou mesmo alguma ideologia em voga no passado, pode ter voltado ao contexto brasileiro, como num processo histórico atávico. De forma mais direta, a autora pode estar se referindo ao abalo democrático sofrido pelo Brasil, pós-impeachment da ex-presidenta Dilma Rousseff, deixando claras as condições propícias para que acontecimentos históricos como, por exemplo, a Ditadura Militar -implantada no Brasil em 1964 e findada em 1985, com a reabertura democráticapossam ressurgir de forma atávica.

Na sequência, segue-se uma autodescrição em primeira pessoa do plural, que alude à concepção que a poeta faz da atual situação da nação brasileira: "Somos um rio seco, sem curso. / Somos um poço escuro e profundo, / Onde não vivem sequer bagres 
albinos. / Discurso para desertos, para ossos e rochedos, / Para homens surdos e mulheres apáticas. / Somos um Paraguaçu de fósseis, de lembranças marinhas" (SANTANA, 2017, p. 153).

Nota-se a explícita associação entre o rio Paraguaçu- que banha o estado da Bahiae o povo brasileiro, através de jogos de significados que vão se estabelecendo, no decorrer do poema, como, por exemplo, quando Santana (2017, p. 153-54) diz que vento brando algum é capaz de suavizar as dores do presente. Resta claro que o eu enunciativo encontra-se em total desesperança, haja vista que ela não vislumbra futuro ou saída, apenas forcas e guilhotinas de condenados suicidas:

Além da devastação em nossas margens, / Aragem alguma suaviza as dores do presente. / Não vislumbro novas galáxias. / Apenas patíbulos de condenados suicidas. / Apenas juízes e delatores, / Apenas sigilos oportunos. / Há um vazamento de tristezas em nossos olhos, / Cataratas mudas aguardam a vertigem do Espírito do / Tempo. / E desencantos mofam nossas paredes. / Como mulher: dilato-me! Por todas as casas do País há plantação de palmas. / E almas perecem de sede e desencanto. Mucugê é um jardim de pedras / Cujas pétalas são nossos corações embrutecidos. O cafezal ameaça as flores do lugar. / O manguezal avança sobre sutilezas de cores.

Seguindo a leitura do poema, nota-se que outro ponto corrobora a hipótese levantada nesta análise, a saber, a proposição de que a poeta faz menção ao momento político delicado pelo qual passa o Brasil, desde 2016, com a culminância do processo de deposição da presidenta Dilma Rousseff, resultando na cassação do seu mandato e inaugurando uma agenda política, que não passou pelo processo democrático de escolha nas urnas eleitorais. Nos versos: “Não vislumbro novas galáxias. / Apenas patíbulos de condenados suicidas. / Apenas juízes e delatores, / Apenas sigilos oportunos. / Há um vazamento de tristezas em nossos olhos" (SANTANA, 2017), é possível fazer conexões 
entre as palavras da autora e os acontecimentos, envolvendo delações premiadas e juízes, que mexeram com a opinião pública brasileira entre os anos de 2016 e 2017, além dos vazamentos de áudio, que puseram a nu os conchavos e alianças dos bastidores de jogos de poder no Brasil.

A seguir, Santana afirma que o aneurisma que explodiu no país, também existe nela e nas demais pessoas justas e naqueles que buscam alegrias coletivas, o que supostamente faz alusão aos movimentos coletivos, cujas pautas giram em torno dos direitos das minorias: “Há um aneurisma em mim / Que também explodirá! / Há um aneurisma nos justos / E naqueles que buscam alegrias coletivas. / Canso-me dos homens / E dos tentáculos da sua arrogância / Que invadem meus abismos, / Minhas sutilezas, minhas cerâmicas, meus musgos" (SANTANA, 2017, p. 154).

Nota-se que, pela primeira vez no poema, Santana faz referência direta aos homens, mas a autora não se refere ao homem, enquanto sujeito masculino, mas ao homem como elemento neutro que representa toda a humanidade. Quando afirma seu cansaço com relação à estupidez, à obscuridade, à inércia, à velhice precoce e à adolescência eterna, à covardia, à desistência e ao desamor, ela parece estar se referindo ao ser humano em geral: "Canso-me dos homens / E da sua estupidez de pedra / Da sua obscuridade de gruta, / Seu estado de inércia, / Sua velhice precoce, / Sua adolescência perpétua. / Sua covardia de demônios. / Sua desistência, seu desamor" (SANTANA, 2017, p. 154).

Neste momento do poema, Santana leva o leitor ao ponto alto de sua enunciação, sob a perspectiva de análise feminista. Ao se autodenominar como uma mulher negra e latino-americana, a autora se posiciona em seu locus social, relata sua ancestralidade africana e expõe as identidades que compõem seu estar no mundo. Além disso, a poeta 
evidencia a importância de ser uma mulher negra escritora e como o ato de escrever a localiza, ao mesmo tempo em que Ihe dá mobilidade, posto que sua pena, ao mesmo tempo em que é sua bússola, também é sua nau: "Sou uma mulher da América Latina! / Sou uma voz diaspórica, negra! / Venho de uma África que me busca. / E o que faço é atravessar oceanos, / Decifrá-la em mim, em meu território. Minha pena é o meu remo. / Minha pena é a minha bússola. / Minha pena é também minha nau" (SANTANA, 2017, p. 154).

Ao se autoproclamar "uma voz diaspórica", Santana (2017) declara, de forma bastante lúcida, a consciência de sua ancestralidade e, assim, como o povo africano do qual descende, a escritora afirma atravessar oceanos. Neste ponto, volta-se a observar como a poeta estabelece entrecruzamento de sentidos e faz do dialogismo e da intertextualidade pontos marcantes de seu texto. $\mathrm{O}$ ato de "atravessar oceanos" remete ao fenômeno da diáspora negra, que marcou de forma definitiva e significativa o povo africano, nos séculos XVI e XIX, posto que conduziu forçosamente homens, mulheres e crianças africanas, em direção às colônias, na condição de escravizados, para fins mercantis.

Outro detalhe importante é a disposição da expressão diaspórica, negra! no poema. Ao utilizar uma vírgula entre os vocábulos e uma exclamação ao final, a autora transforma a expressão, um tanto carregada de sentido negativo, na afirmação de uma identidade, como se vê: "Sou uma voz diaspórica, negra!", o tom exclamativo conota a afirmação contundente de um dos componentes de sua identidade - escritora de pele negra, ela sabe que tem muito de África em sua composição identitária.

Não obstante, com relação ao resgate dos laços de identidade, que ligam os afrodescendentes aos locais periféricos de poder, Davis (2017), na obra Mulheres, Cultura 
e Política, coloca a busca por dignidade e pela liberdade à frente de qualquer busca identitária:

Embora tenhamos identificado que os laços que nos ligam à África, à Ásia, ao Caribe, ao Oriente Médio e à América Latina foram moldados por nossas respectivas heranças culturais e raciais. Devemos estar igualmente cientes do fato de que elas têm sido imensamente fortalecidas por nossa busca comum pela dignidade e pela liberdade (DAVIS, 2017, p. 157).

No contexto de uso da linguagem como forma de resistência, Ribeiro alerta às feministas negras e latinas, como a autora do poema, em análise, com relação ao poder do uso da linguagem, como ferramenta de opressão:

Importante ressaltar o quanto é fundamental para muitas feministas negras e latinas a reflexão de como a linguagem dominante pode ser utilizada como forma de manutenção de poder, uma vez que exclui indivíduos que foram apartados das oportunidades de um sistema educacional justo. A linguagem, a depender da forma como é utilizada, pode ser uma barreira ao entendimento e criar mais espaço de poder em vez de compartilhamento, além de ser um- entre tantos outrosimpeditivo para uma educação transgressora (RIBEIRO, 2017, p. 26).

Santana (2017, p. 154) segue declarando seu cansaço com relação aos homens, mas, neste ponto do poema, ela opta por associá-los a animais com características ligadas às atitudes negativas e sorrateiras, como os abutres, as raposas e os leopardos: "Cansome dos abutres, das raposas, / Dos leopardos e da prepotência dos intelectuais. / Ninguém me faz feliz! / Ninguém tem a chave! / Quem nutre a memória de mim? / Quem projeta meus delírios em suas cavernas?" 
Nos próximos versos do poema, é possível identificar a utilização do substantivo poder, relacionando-o aos homens brancos, o que direciona a análise a uma crítica direta da autora com relação à supremacia masculina branca: "Há o vício dos brancos, o vício do poder dos homens". Nota-se aqui, que a poeta pensa as formas de opressão de maneira conjunta, interseccionada. Quando elenca: brancos e homens, ela coloca em cena dois privilégios, que asseguram o acesso ao poder e, portanto, duas possibilidades de opressão: pela cor e pelo gênero.

Segundo Scott (2002, p. 37), a superioridade do homem branco ocidental não se estabelecia exclusivamente em relação às mulheres, mas também em relação aos seus homólogos de cor negra:

[...] o indivíduo universal que exercia os direitos políticos de "homem" era ao mesmo tempo abstrato e concreto; sua diferença em relação à mulher (em termos de desejo ou de função reprodutiva) Ihe assegurava tanto seu status genérico de homem como os limites de sua individualidade. A individualidade não era apenas uma prerrogativa masculina; era também definida em termos de raça (SCOTT, 2002, p. 37).

Ideia que é corroborada pela relação entre feminismo e desconstrução, emitida por Santana (2017), logo nos versos subsequentes: "Sou feminista quando me desconstruo, / Travo embates com a existência / E enfrento temores". Além disso, a poeta afirma a existência de estalactites nos cérebros e, entre o sexo e alma. Estalactites são formações rochosas que se formam normalmente no teto de uma gruta ou caverna. É interessante notar que estas sedimentações crescem de cima para baixo, lentamente, tendendo ao chão - logo, a autora quis demonstrar um movimento de caída e não de elevação. Enquanto as estalagmites são formações rochosas que se formam de baixo para 
cima, vinculando a autora ao sexo de nascença como elemento que prescreve a subjetividade feminina, de forma impositiva:

Há um ranço de família na poeira das mobílias. / Ranço de nomes na cartografia das lápides. / Ranço do poder na energia das vozes, / $\mathrm{Na}$ seleção dos vocábulos. / Há o vício dos brancos, o vício do poder dos homens. Sou feminista quando me desconstruo, / Travo embates com a existência/ $E$ enfrento temores. Há um ranço de poder nas elites. / Há estalactites nos cérebros, / Estalagmites entre o sexo e a alma (SANTANA, 2017, p. 154).

Em seguida, a poeta lança o olhar para sua composição psíquica e realiza uma espécie de constatação de sua solidão no mundo:

Há desvãos insondáveis dentro de mim. / Ninguém me acha, ninguém me vê, / E, hoje, ninguém me habita. / Há um labirinto dentro de mim, / Que apenas eu me percorro solitariamente aos domingos. / Apenas eu mínguo de vésperas e de escolhas. / Apenas eu recolho âncoras / E trago pavões em minhas saias. / Dragões e mandrágoras residem nas rendas / Das minhas negras anáguas. / Apenas eu sou casta, / Pois vivencio a solidão absoluta das divindades (SANTANA, 2017, p. 154).

Santana (2017, p. 155) continua descrevendo algumas características psicológicas, relatando alguns sentimentos e sensações, deixando inicialmente transparecer que existem motivações individuais para este estado de espírito. Mas algumas referências mostram que, para além das angústias individuais sofridas pela escritora, existem motivos sociais e políticos que determinam tal estado de espírito. Começando quando ela afirma que "a história é feita por fios que se desfazem", seguido pela afirmação de "Os girassóis de Van Gog estão mortos" e culmina no assombra com as conspirações e golpes, fazendo mais uma vez menção ao impeachment da ex-presidenta Dilma Rousseff: 
Trago em mim a ilusão de reter o tempo, / A extensão da vida, da morte. / Inútil reter a convulsão dos diamantes! / E a combustão dos diademas. / Inútil reter sementes, óvulos e afetos! / Inútil, pois o belo expira. / 0 amor definha. / E a história é feita de fios que se desfazem / No ano do Galo. / Restam vestígios e sombras apenas. / Os girassóis de Van Gogh estão mortos! / Somente agora os vejo cadáveres. / Somente agora murcham e enlouquecem / Diante das minhas janelas barrocas. / Há desolação em meu peito / E o coração assombra-se com / Conspirações, golpes.

Por fim, a autora fala de si como se saísse do seu corpo e se visse em sua escrivaninha, em giros de convulsão do mundo, ao passo em que transita por vários universos imaginários, experimentando uma espécie de epifania. A poeta descrita por Santana (2017, p. 155) parece chegar ao estágio máximo de consciência, prefere não o ter e ordena que trouxessem três substâncias que lhe permitiram subtrair a realidade: o ópio, o haxixe e o absinto:

\begin{abstract}
A Poeta cisma da sua escrivaninha / E gira na convulsão do mundo. / A Poeta transita entre as minas de ouro da Colômbia / Em amnésia, em guilhotinas, em fraudes. / Atordoada de si mesma e da sua condição. / O estúpido americano ataca a língua de Lorca! / O Chile, em incêndios. / Imigrantes sofrem açoites, pânicos. / Tudo o que canto faz-se poeira cósmica. / Tudo o que canto evade-se sem eco. / Tragam-me o ópio, o haxixe e o absinto!
\end{abstract}

Em síntese, a poesia de Rita Santana é constituída de variadas paletas de significações, que têm consonância com as pautas do movimento feminista negro, bem como com as ideias desenvolvidas no contexto de um feminismo interseccional. Além do mais, as intertextualidades presentes no poema levam o leitor a refletir sobre o contexto social e histórico do Brasil contemporâneo - o que o torna ainda mais pertinente. 


\section{Referências}

BLOOM, Harold. "Elegíaal Canon". In: El canon literario. Enric Sullà. (org.). Madrid: Arco/Libros, S. L., 1998. p. 189-219.

BUTLER, Judith. Problemas de gênero: Feminismo e subversão da identidade. Tradução Renato Aguiar.Rio de Janeiro: Editora Civilização Brasileira, 2017.

CARNEIRO, Sueli. Racismo, sexismo e desigualdade no Brasil. São Paulo: Selo Negro, 2011.

COUTINHO, Eduardo F. "Literatura comparada, literaturas nacionais e o questionamento do cânone". In: Revista Brasileira de Literatura Comparada. Rio de Janeiro: ABRALIC, n 3, 1996. p. 67-73.

COLLIN, Françoise.Diferença dos sexos (teorias da). In: HIDRATA, H.; LABORIE, F.; LE DOARÉ, H.; SENOTIER, D. (orgs.). Dicionário crítico do feminismo. São Paulo: Editora UNESP, 2009. p. 59-66.

DAVIS, Angela. Mulheres, raça e classe. Tradução Heci Regina Candini. São Paulo, Boitempo, 2016.

DAVIS, Angela. Mulheres, cultura e política. Tradução Heci Regina Candini. São Paulo, Boitempo, 2017.

FERNANDES, Danubia de Andrade. O Gênero negro: apontamentos sobre gênero feminismo e negritude. Estudos Feministas. Florianópolis:UFSC, 24(3), setembro/dezembro, 2016. p.691-713.

GALDINO, D. Irmandades pelo grito. In: Daniela Galdino. (org.). Profundanças 2. Ipiaú: Voo Audiovisual, 2017. p. 07.

GROSZ, Elizabeth. Corpos reconfigurados. Cadernos Pagu. Campinas: Unicamp, (14), 2000. p. $45-86$.

LAJOLO, Marisa. Sociedade e literatura: parceria sedutora e problemática. In: ORLANDI, Eni Puccinelli; LAJOLO, M.; IANNI, O. (orgs.). Sociedade e Linguagem. Campinas: Ed. UNICAMP, 1997.

MIGNOLO, Walter. "Los cânones y (más allá de) las fronteras culturales". In: SULLÀ, Enric (org.). El canon literario.. Madrid: Arco/Libros, S. L., 1998. p. 237-270.

RIBEIRO, Djamila. O que é lugar de fala? Belo Horizonte: Letramento: Justificando, 2017. 
RICH, Adrianne. Sobre mentiras, secretos y silencios. Barcelona: Icaria, 1983.

RIOT-SARCEY, Michèle. "Poder(es)".Tradução Francisco Ribeiro Silva Júnior. In: HIDRATA, H.; LABORIE, F.; LE DOARÉ, H.; SENOTIER, D (orgs.). Dicionário crítico do feminismo. São Paulo: Editora UNESP, 2009. p. 183-188.

ROBINSON, Lillian S. Traicionandonuestro texto. Desafíos feministas al canon literario. In: SULLÀ, Enric. (org.). El canon literario. Madrid: Arco/Libros, S. L., 1998. p. 115-137.

SANTANA, Rita. Panfleto para Pirilampos e Magnólias. In: GALDINO, Daniela. (org.). Profundanças 2. Ipiaú: Voo Audiovisual, 2017. p. 153-155.

SCHMIDT, Rita T. Descentramento / convergências: ensaios de crítica feminista. Porto Alegre: UFRGS Editora, 2017.

SPIVAK, Gayatri Chakravorty. Pode o subalterno falar? Tradução Sandra Regina Goulart Almeida, Marcos Pereira Feitosa e André Pereira Feitosa. Belo Horizonte: Editora UFMG, 2010.

SCOTT, Joan W. A cidadã paradoxal: as feministas francesas e os direitos do homem. Tradução Élvio Antônio Funck. Florianópolis: Mulheres, 2002.

Recebido em 27 de maio de 2019.

Aceite em 06 de agosto de 2019. 